\title{
Protection and Management of Species, Habitats, Ecosystems and Landscapes: Current Trends and Global Needs
}

\author{
Panayotis Dimopoulos * (D) and Ioannis P. Kokkoris \\ Department of Biology, Laboratory of Botany, University of Patras, 26504 Patras, Greece; ipkokkoris@upatras.gr \\ * Correspondence: pdimopoulos@upatras.gr; Tel.: +30-2610-996777
}

Received: 8 November 2020; Accepted: 23 November 2020; Published: 25 November 2020

\begin{abstract}
Human well-being and the prerequisite sustainable environmental management are currently at stake, reaching a bottleneck when trying to cope with (i) the ever-growing world population, (ii) the constantly increasing need for natural resources (and the subsequent overexploitation of species, habitats, ecosystems, and landscapes) and (iii) the documented and on-going impacts of climate change. In developed societies, the concern about environmental protection is set high in the public dialogue, as well as to management and policy agendas. The recently constituted Intergovernmental Science-Policy Platform on Biodiversity and Ecosystem Services (IPBES) urges transformative changes for technological, economic, and social factors aiming to tackle both direct and indirect drivers of biodiversity loss. By this, the role of conservation and management practices for the environment is characterized as a crucial and top issue and should deal with (a) promoting best practices from the local to the global level, (b) identifying spatial and temporal knowledge gaps, (c) multidisciplinary aspects for sustainable management practices, (d) identifying and interpreting the role of stakeholders and socio-economic parameters in the decision-making process, and (e) methods and practices to integrate the concept of ecosystem services into natural capital assessment and accounting, conservation and management strategies. Modern literature highlights that land-use change and prioritization, restoration of natural areas, cultural landscape identification and maintenance, should be considered to the top of the scientific and policy agenda, as well as to the epicenter of novel awareness-raising strategies for the environment in the near future.
\end{abstract}

Keywords: conservation management; conservation status assessment; ecosystem condition assessment; ecosystem services; natural capital; spatial patterns; species and habitats monitoring; sustainable practices; temporal patterns

During the last two decades our understanding about how ecosystems and the relevant biodiversity attributes interact with human society has been scientifically increased, highlighting their importance to the quality of life and human well-being [1]. Important initiatives triggered science-policy interactions worldwide, based on the results of multidisciplinary approaches and case studies, e.g., [2,3]. The importance of this interaction and co-existence of biodiversity, ecosystems in good condition and socio-economic prosperity is recently studied by the Global Assessment of Biodiversity and Ecosystem Services, under the Intergovernmental Science-Policy Platform on Biodiversity and Ecosystem Services (IPBES) initiative [4]; the relevant summary of the assessment was approved in 2019, by more than 130 Governments, which constitute the Members of IPBES [1]. The results of this extensive review and these analyses support the findings of the Millennium Ecosystem Assessment, presented 15 years ago (in 2005) [5], encouraging relevant, ongoing, national and local projects, and urges for new efforts on pilot studies and implementation actions. Already, many countries are on this track, implementing projects regarding capacity building, methodological standardization 
and drafting typologies (e.g., [6-11]), while 'umbrella' projects provide guidance to standardize and mainstream the efforts in a wider scale (e.g., the ESMERALDA [12] and MAIA [13] Horizon 2020 projects in the European Union). Even more multidisciplinary studies are published during the last decade [14], indicating an increased trend; numerous future-projection assessments are also provided from global (e.g., [15-17]) to local level (e.g., [18,19]), based mainly on climatic and/or management scenarios, aiming to support decision making and policy needs for a sustainable management drafting.

Simultaneously, the United Nations Statistical Commission endorsed the System of Environmental-Economic Accounting-Experimental Ecosystem Accounting (SEEA EEA) as the basis for commencing testing and further development of natural capital accounting [20]. Further work has been conducted aiming to raise awareness about, propose and demonstrate a set of concepts that are needed to understand ecosystems as assets in natural capital accounting [21]. To fulfill this promising task (even at its initial stages), (a) aspects of ecosystem extent, ecosystem condition and ecosystem services (capacity, supply and potential supply) at different scales (i.e., local, regional and national) should be considered and (b) baseline assessments are needed starting with relevant data gathering, modelling, assessments and time series development. This need calls for robust scientific information on various aspects of ecosystems' characteristics, including area cover, biodiversity and functioning, as well as of human activities and interactions ranging from industrial activity to intellectual use and aesthetic value.

It is evident that this complex scientific environment and the multi-disciplinarity needed for this holistic approach presupposes robust spatially assigned scientific evidence from natural and environmental sciences, as well as from humanitarian sciences and the socio-economic filed. Moreover, examples from case-studies implemented in different places around the globe should be considered for knowledge transfer and replication to meet local needs in similar conditions. The purpose of this Special Issue (SI) is to contribute to this effort by presenting case examples from different regions of the world dealing with biodiversity, habitat dynamics, management scenarios, human-nature interaction and policy initiatives on biodiversity and ecosystem services. We believe that the papers published in this SI provide scientific evidence on various aspects of nature conservation and management aiming to support win-win opportunities for human activities within the environment, which are considered as increasingly scarce in a 'full' global, ecological-economic system [22].

Author Contributions: Both authors contributed to the writing of this editorial. Both authors have read and agreed to the published version of the manuscript.

Funding: This research received no external funding.

Conflicts of Interest: The authors declare no conflict of interest.

\section{References}

1. IPBES. Global Assessment Summary for Policymakers; Díaz, S., Settele, J., Brondízio, E.S., Ngo, H.T., Guèze, M., Agard, J., Arneth, A., Balvanera, P., Brauman, K.A., Butchart, S.H.M., Eds.; IPBES Secretariat: Bonn, Germany, 2019.

2. TEEB. The Economics of Ecosystems and Biodiversity: Mainstreaming the Economics of Nature: A synthesis of the Approach, Conclusions and Recommendations of TEEB; TEEB: Madhya Pradesh, India, 2010; ISBN 9783981341034.

3. Maes, J.; Teller, A.; Erhard, M.; Liquete, C.; Braat, L.; Berry, P.; Egoh, B.; Puydarrieus, P.; Fiorina, C.; Santos, F.; et al. Mapping and Assessment of Ecosystem and their Services. An Analytical Framework for Ecosystem Assessments under Action 5 of the EU Biodiversity Strategy to 2020; Publications office of the European Union: Luxemburg, 2013; ISBN 9789279293696.

4. IPBS. Global Assessment Report on Biodiversity and Ecosystem Services of the Intergovernmental Science-Policy Platform on Biodiversity and Ecosystem Services; Brondizio, E.S.J., Settele, S.D., Ngo, H.T., Eds.; IPBES Secretariat: Bonn, Germany, 2019.

5. Millenium Ecosystem Assessment. Ecosystems \& Human Well-Being; Island Press: Washington, DC, USA, 2005.

6. Haines-Young, R.; Paterson, J.; Potschin, M.; Wilson, A.; Kass, G. The UK NEA Scenarios: Development of Storylines and Analysis of Outcomes. In The UK National Ecosystem Assessment Technical Report; UK National Ecosystem Assessment, United Nations Environment Programme/World Conservation Monitoring Centre: Cambridge, UK, 2011; pp. 1195-1264. 
7. Spanish National Ecosystem Assessment. Ecosystems and Biodiversity for Human Wellbeing: Synthesis of Key Findings; Ministerio de Agricultura, Alimentación y Medio Ambien: Madrid, Spain, 2014.

8. Van Reeth, W. Ecosystem Service Indicators in Flanders: Are we Measuring What we Want to Manage? Instituut voor Natuuren Bosonderzoek: Brussel, Belgium, 2014.

9. Albert, C.; Bonn, A.; Burkhard, B.; Daube, S.; Dietrich, K.; Engels, B.; Frommer, J.; Götzl, M.; Grêt-Regamey, A.; Job-Hoben, B.; et al. Towards a national set of ecosystem service indicators: Insights from Germany. Ecol. Indic. 2016, 61, 38-48. [CrossRef]

10. Grunewald, K.; Syrbe, R.U.; Walz, U.; Richter, B.; Meinel, G.; Herold, H.; Marzelli, S. Germany's ecosystem services—state of the indicator development for a nationwide assessment and monitoring. One Ecosyst. 2017, 2, e14021. [CrossRef]

11. Kokkoris, I.P.; Mallinis, G.; Bekri, E.S.; Vlami, V.; Zogaris, S.; Chrysafis, I.; Mitsopoulos, I.; Dimopoulos, P. National set of MAES indicators in Greece: Ecosystem services and management implications. Forests 2020, 11, 595. [CrossRef]

12. ESMERALDA (Enhancing Ecosystem Services Mapping for Policy And Decision Making). Available online: http://www.esmeralda-project.eu/ (accessed on 12 April 2020).

13. Mapping and Assessment For Integrated Ecosystem Accounting (MAIA). Available online: https://maiaportal. eu/ (accessed on 7 November 2020).

14. Costanza, R.; de Groot, R.; Braat, L.; Kubiszewski, I.; Fioramonti, L.; Sutton, P.; Farber, S.; Grasso, M. Twenty years of ecosystem services: How far have we come and how far do we still need to go? Ecosyst. Serv. 2017, 28, 1-16. [CrossRef]

15. Schröter, D.; Cramer, W.; Leemans, R.; Prentice, I.C.; Araújo, M.B.; Arnell, N.W.; Bondeau, A.; Bugmann, H.; Carter, T.R.; Gracia, C.A.; et al. Ecology: Ecosystem service supply and vulnerability to global change in Europe. Science 2005, 310, 1333-1337. [CrossRef] [PubMed]

16. Di Marco, M.; Harwood, T.D.; Hoskins, A.J.; Ware, C.; Hill, S.L.L.; Ferrier, S. Projecting impacts of global climate and land-use scenarios on plant biodiversity using compositional-turnover modelling. Glob. Chang. Biol. 2019, 25, 2763-2778. [CrossRef] [PubMed]

17. Nunez, S.; Arets, E.; Alkemade, R.; Verwer, C.; Leemans, R. Assessing the impacts of climate change on biodiversity: Is below $2{ }^{\circ} \mathrm{C}$ enough? Clim. Change 2019, 154, 351-365. [CrossRef]

18. Dai, E.; Wu, Z.; Ge, Q.; Xi, W.; Wang, X. Predicting the responses of forest distribution and aboveground biomass to climate change under RCP scenarios in southern China. Glob. Chang. Biol. 2016, 22, 3642-3661. [CrossRef] [PubMed]

19. Kokkoris, I.P.; Bekri, E.S.; Skuras, D.; Vlami, V.; Zogaris, S.; Maroulis, G.; Dimopoulos, D.; Dimopoulos, P. Integrating MAES implementation into protected area management under climate change: A fine-scale application in Greece. Sci. Total Environ. 2019, 695, 133530. [CrossRef] [PubMed]

20. United Nations; European Commission; Food and Agricultural Organization of the United Nations; Organization for Economic Co-Operation and Development; World Bank. System of Environmental-Economic Accounting 2012: Experimental Ecosystem Accounting; United Nations: New York, NY, USA; European Commission: Brussels, Belgium; Food and Agricultural Organization of the United Nations: Rome, Italy; Organization for Economic Co-Operation and Development: Paris, France; World Bank: Washington, DC, USA, 2014; ISBN 9789210559263.

21. Hein, L.; Bagstad, K.; Edens, B.; Obst, C.; De Jong, R.; Lesschen, J.P. Defining ecosystem assets for natural capital accounting. PLoS ONE 2016, 11, e0164460. [CrossRef] [PubMed]

22. Costanza, R.; Daly, H.E. Natural Capital and Sustainable Development. Conserv. Biol. 2007, 6, 37-46. [CrossRef]

Publisher's Note: MDPI stays neutral with regard to jurisdictional claims in published maps and institutional affiliations.

(C) 2020 by the authors. Licensee MDPI, Basel, Switzerland. This article is an open access article distributed under the terms and conditions of the Creative Commons Attribution (CC BY) license (http://creativecommons.org/licenses/by/4.0/). 